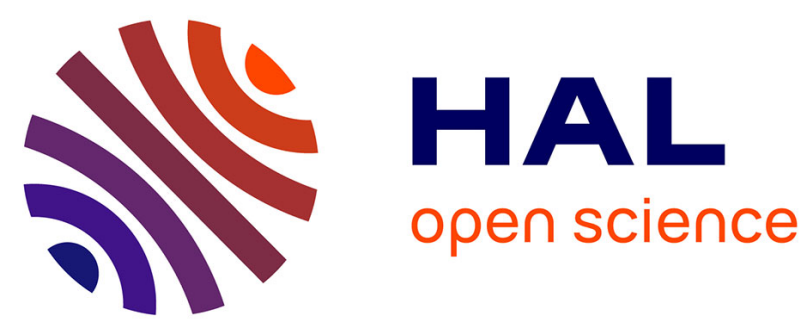

\title{
Biotransformation enzyme activities in the olfactory organ of rainbow trout (Oncorhynchus mykiss). Immunocytochemical localization of cytochrome P4501A1 and its induction by beta-naphthoflavone
} Gilles Monod, D. Saucier, E. Perdu-Durand, M. Diallo, Jean Pierre J. P. Cravedi, L. Astic

\section{To cite this version:}

Gilles Monod, D. Saucier, E. Perdu-Durand, M. Diallo, Jean Pierre J. P. Cravedi, et al.. Biotransformation enzyme activities in the olfactory organ of rainbow trout (Oncorhynchus mykiss). Immunocytochemical localization of cytochrome P4501A1 and its induction by beta-naphthoflavone. Fish Physiology and Biochemistry, 1994, 13 (6), pp.433-444. 10.1007/BF00004326 . hal-02713506

\author{
HAL Id: hal-02713506 \\ https://hal.inrae.fr/hal-02713506
}

Submitted on 1 Jun 2020

HAL is a multi-disciplinary open access archive for the deposit and dissemination of scientific research documents, whether they are published or not. The documents may come from teaching and research institutions in France or abroad, or from public or private research centers.
L'archive ouverte pluridisciplinaire HAL, est destinée au dépôt et à la diffusion de documents scientifiques de niveau recherche, publiés ou non, émanant des établissements d'enseignement et de recherche français ou étrangers, des laboratoires publics ou privés. 


\title{
Biotransformation enzyme activities in the olfactory organ of rainbow trout (Oncorhynchus mykiss). Immunocytochemical localization of cytochrome P4501A1 and its induction by $\beta$-naphthoflavone
}

\author{
G. Monod ${ }^{1}$, D. Saucier ${ }^{2}$, E. Perdu-Durand 3 , M. Diallo 4 , J.-P. Cravedi ${ }^{3}$ and L. Astic ${ }^{4}$ \\ ${ }^{1}$ Laboratoire d'Ecotoxicologie Aquatique, INRA, 65 Rue de St-Brieuc, 35042 Rennes Cédex, France; \\ ${ }^{2}$ Université de Moncton, Centre Universitaire/Aquarium et Centre Marin, Shippagan, N.B., Canada \\ EOB 2P0; ${ }^{3}$ Laboratoire des Xénobiotiques, INRA, 180 Chemin de Tournefeuille, 31931 Toulouse \\ Cédex, France; ${ }^{4}$ Laboratoire de Physiologie Neurosensorielle, UCB/Lyon I, 69622 Villeurbanne Cédex, \\ France
}

Accepted: June 24, 1994

Keywords: rainbow trout, olfactory organ, biotransformation enzyme, cytochrome P4501A1, EROD, testosterone hydroxylase, p-nitrophenol hydroxylase, glutathione $S$-transferase, immunocytochemistry, induction, $\beta$-naphthoflavone

\begin{abstract}
Olfaction is a crucial function in most fish species, but little is known about biotransformation enzymes in the olfactory organ. This study demonstrates that biotransformation enzymes usually found in the rainbow trout liver, are present in the olfactory organ as well. While microsomal cytochrome $\mathrm{P} 450$ reductase, $\mathrm{p}$-nitrophenol hydroxylase and cytosolic glutathione $S$-transferase presented similar levels in both the olfactory organ and the liver, microsomal 7-ethoxyresorufin $O$-deethylase (EROD), 7-ethoxycoumarin $O$-deethylase, and 7-pentoxyresorufin $O$-deethylase were much lower in the olfactory organ (77-, 35-, 200-times respectively). Furthermore, microsomes from the olfactory organ were able to perform testosterone hydroxylation only in the $16 \alpha$-position while testosterone was hydroxylated in the $16 \beta$-position by liver microsomes. Using polyclonal antibodies raised against perch cytochrome P4501A1, the immunoreactive protein was shown to be strongly expressed in various cellular types forming the nonsensory epithelium. Some immunostaining was also reported in the nonsensory cellular elements constituting the sensory epithelium, while olfactory receptor cells failed to show cytochrome P4501A1-immunoreactivity. Finally, the exposure of rainbow trout to waterborne $\beta$-naphthoflavone $\left(0.1 \mu \mathrm{g} \mathrm{m}^{-1}\right)$ for 2 or 4 days resulted in a higher induction of EROD activity in the olfactory organ compared to the liver. The presence of biotransformation enzymes in the olfactory organ of rainbow trout addresses the question of their involvement in the detoxication/toxication of pollutants as well as in the olfactory function.
\end{abstract}

\section{Introduction}

Biotransformation enzymes are involved in the metabolism of exogenous and numerous endogenous compounds such as steroids, bile acids, prostaglandins. They are divided into two classes: phase I and phase II. Phase I enzymes are mainly represented by cytochromes $\mathrm{P} 450$ which catalyze the insertion of one atom of oxygen into the substrate. Phase II enzymes (glutathione $S$-transferase, UDP glucuronosyltransferase, sulfotransferase) catalyze conjugation of endogenous substrates with oxygenated substrates, including products of phase I metabolism. First investigated in the liver, biotransformation enzymes have now been detected to a greater or lesser extent in almost every mammalian tissue. In- 
terestingly, levels of phase I and phase II enzymes may be induced by xenobiotics and endogenous compounds, thus suggesting their role in cellular homeostasis (Nebert 1991). The mechanism of cytochrome P4501A1 induction has been extensively studied (Nebert et al. 1993; Okey 1990).

In fish, numerous studies have demonstrated the presence of biotransformation enzymes showing similarities with corresponding mammalian enzymes (Chambers and Yarbrough 1976). Nevertheless, studies were performed mainly in the liver and to a lesser extent in kidneys and gills, whereas other extrahepatic tissues were rarely investigated. Induction of fish hepatic cytochrome $\mathrm{P} 450$ has been used as a biomarker of the pollution of aquatic environments by chemical toxicants (Goksøyr and Förlin 1992; Monod et al. 1988; Payne et al. 1987).

During the last few years, more attention has been paid to biotransformation enzymes in the mammalian nasal epithelium and particularly in the olfactory epithelium (for review, see Dahl and Hadley 1991; Reed 1993). It has been suggested that these enzymes should be involved in the metabolism of xenobiotics susceptible to alter odor perception, as well as in the regulation of levels of odorous compounds (Dahl and Hadley 1991).

In fish, olfaction is a crucial function for food detection, social behavior and reproduction (Hara 1993). Furthermore, the receptor cells in the fish olfactory organ are neurons which are in direct and permanent contact with waterborne pollutants. The olfactory system which appears poorly protected may be vulnerable to toxicant action, particularly by this route of exposure (Saucier et al. 1991; Klaprat et al. 1992). Unfortunately, few data are available on biotransformation enzymes in the fish olfactory organ. Some cytochrome P450-dependent activity has been deduced from $\mathrm{CO}_{2}$ formation after incubation of rainbow trout olfactory rosettes with $\left({ }^{14} \mathrm{C}\right)$-phenacetin (Brittebo et al. 1986). More recently, using a specific antibody, cytochrome P4501 A has been detected in the olfactory organ of topminnows (Poeciliopsis sp.) (Smolowitz et al. 1992).

In the present study, we have prepared subcellular fractions from the olfactory organ and the liver of rainbow trout to compare the activity of xeno- biotic metabolizing enzymes in both structures. Phase I and phase II biotransformation enzymes already described in the olfactory organ of mammals have been assessed. Using polyclonal antibodies raised against perch cytochrome $\mathrm{P} 4501 \mathrm{~A}$ which is known to react specifically with rainbow trout cytochrome P4501A1, we have also determined by immunocytochemical approach in which cell types within the nonsensory and the sensory epithelia, the cytochrome P4501A1 is located. Finally, as hepatic cytochrome P4501A1 is inducible by $\beta$-naphthoflavone (Goksøyr and Förlin 1992), we have studied the effect of waterborne exposure to this planar compound on 7-ethoxyresorufin $O$-deethylase, a cytochrome P4501A1-dependent activity, in the olfactory organ as well as in the liver.

\section{Materials and methods}

\section{Fish}

Cultured, immature rainbow trout, Oncorhynchus mykiss, of both sexes were obtained from a local hatchery. For enzymatic measurements and immunocytochemical investigations in control fish, tissues were sampled directly at the hatchery.

\section{Chemicals}

Cytochrome $c$, reduced glutathione, 7-ethoxyresorufin, 7-pentoxyresorufin, reduced nicotinamide adenine dinucleotide phosphate (NADPH), dithiothreitol (DTT) and phenyl methyl sulfonyl fluoride (PMSF) were purchased from BoehringerMannheim, Meylan, France. Testosterone, 16 $\alpha$ hydroxytestosterone, 7-ethoxycoumarin, ethylene diamino tetraacetate (EDTA), $\alpha$-naphthoflavone (7,8-benzoflavone), $\beta$-naphthoflavone $(5,6$-benzoflavone), $\left[{ }^{14} \mathrm{C}\right]-4-$ nitrophenol (pNP, specific activity $11.7 \mathrm{mCi} \mathrm{mmol}^{-1}$ ) and 4-nitrocatechol (pNC) were obtained from Sigma Chemicals, St Quentin Fallavier, France. $\left[4-{ }^{14} \mathrm{C}\right]$-testosterone (specific activity $49 \mathrm{mCi} \mathrm{mmol}^{-1}$ ) was from CEA Saclay, Gifsur-Yvette, France. Lumaflow II scintillation cocktail was obtained from Lumac, Olen, Belgium. 
HPLC-grade methanol was purchased from Prolabo, Paris, France. Rabbit peroxidase-antiperoxidase (PAP) complex was obtained from Dako, Denmark. Other chemicals were of the purest grade available.

\section{Preparation of microsomes of the olfactory organ and the liver}

Trout were decapitated and the olfactory rosettes and the liver were quickly removed. Tissues were

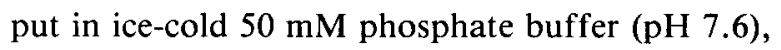
containing $0.15 \mathrm{M} \mathrm{KCl}, 1 \mathrm{mM}$ EDTA, $1 \mathrm{mM}$ DTT. Twelve olfactory rosettes were pooled, then homogenized using a Potter-Elvehjem. Prior to homogenization, PMSF (0.2 mM final), a protease inhibitor, was added. Homogenates of liver were prepared in the same way. The tissue homogenate was centrifuged in a Beckman J-21C centrifuge for 15 min at $10,000 \mathrm{~g}$ at $4^{\circ} \mathrm{C}$. The supernatant was then recentrifuged in a Beckman L8-M ultracentrifuge for $60 \mathrm{~min}$ at $105,000 \times \mathrm{g}$ at $4^{\circ} \mathrm{C}$. The microsomal pellet was resuspended in $50 \mathrm{mM}$ phosphate buffer, $\mathrm{pH} 7.6$, containing $1 \mathrm{mM}$ DTT, $1 \mathrm{mM}$ EDTA, $20 \%$ glycerol, and stored in small aliquots at $-80^{\circ} \mathrm{C}$.

\section{Enzyme assays}

NADPH-cytochrome P450 reductase (cytochrome $\mathrm{P} 450$ reductase) activity was measured by the reduction of cytochrome $c$ at $20^{\circ} \mathrm{C}$ according to Monod et al. (1987), using a Shimadzu spectrophotometer MPS-2000.

7-Ethoxyresorufin $O$-deethylase (EROD), 7-pentoxyresorufin $O$-depentylase (PROD) and 7-ethoxycoumarin $O$-deethylase (ECOD) assays were carried out at $20^{\circ} \mathrm{C}$ in $800 \mu$ l final volume containing $0.1 \mathrm{mM}$ phosphate buffer, $\mathrm{pH} 7.6,0.1 \mathrm{mM}$ NADPH, microsomal protein and $5 \mu \mathrm{M}$ (EROD and PROD) or $500 \mu \mathrm{M}$ (ECOD) substrate added in DMSO (1\% final). For an EROD inhibition study, $\alpha$-naphthoflavone in DMSO (1\% final) was added $3 \mathrm{~min}$ prior to addition of 7 -ethoxyresorufin. The reaction was stopped with $2 \mathrm{ml}$ of acetone (EROD and PROD) or with $100 \mu \mathrm{l}$ of trichloracetic acid
(20\%) (ECOD). The fluorescence of resorufin (EROD and PROD) was measured (after centrifugation) at $583 \mathrm{~nm}$ with an excitation wavelength of $537 \mathrm{~nm}$. The fluorescence of 7-hydroxycoumarin (ECOD) was measured (excitation wavelength: 380 $\mathrm{nm}$; emission wavelength: $480 \mathrm{~nm}$ ) following the procedure previously described (Monod et al. 1987). Fluorescence was measured using a JobinYvon spectro-fluorophotometer JY3-D standardized by resorufin and 7-hydroxycoumarin.

Testosterone hydroxylation was measured by incubation of microsomes $(0.36 \mathrm{mg}$ protein, $750 \mu \mathrm{l}$ $0.1 \mathrm{M}$ HEPES buffer $\mathrm{pH} 7.4$ ) with $200 \mathrm{ng}\left[4-{ }^{14} \mathrm{C}\right]$ testosterone, NADPH, and a NADPH-generating system containing glucose 6-phosphate and glucose 6-phosphate dehydrogenase, for $1 \mathrm{~h}$ at $25^{\circ} \mathrm{C}$. The reaction was stopped by addition of dichloromethane, and testosterone metabolites were immediately extracted with $4 \times 4 \mathrm{ml}$ dichloromethane. Testosterone metabolites were separated by highperformance liquid chromatography (HPLC) as described by Wood et al. (1983) and by thin-layer chromatography (TLC) as reported by Waxman et al. (1983). Metabolites were identified by comparison with authentic standards and quantified using ${ }^{14} \mathrm{C}$ activity monitoring.

Para-nitrophenol (pNP) hydroxylase assays were carried out at $25^{\circ} \mathrm{C}$ in a final volume of $0.5 \mathrm{ml}$ containing $0.1 \mathrm{M}$ phosphate buffer, $\mathrm{pH} 7.4,0.36 \mathrm{mg}$ microsomal protein, NADPH-generating system (Perdu-Durand and Tulliez 1985), and 6.5 nmoles $\left[{ }^{14} \mathrm{C}\right]-\mathrm{pNP}$. The reaction was stopped with $1 \mathrm{ml}$ cold methanol containing $1 \%$ ascorbic acid. After centrifugation at $15,000 \times \mathrm{g}$ for $10 \mathrm{~min}$, the supernatant was evaporated to dryness in a speed vac concentrator (Savant Instruments Inc, Farmingdale, NY, USA) and redissolved in $200 \mu \mathrm{l}$ of methanol. Fifty $\mu \mathrm{l}$ of the methanolic solution were submitted to an HPLC analysis after filtration through a $0.22 \mu \mathrm{m}$ Millex microfilter (Millipore, Molsheim, France). Chromatographic separation was carried out on a $250 \mathrm{~mm} \times 4.6 \mathrm{~mm}$ I.D. ODS 2, $5 \mu \mathrm{m}$ column (SFCC, Eragny, France). The mobile phase was water:methanol $(65: 35)$ adjusted to pH 3.5 with acetic acid and delivered at $1 \mathrm{ml}$ per min with a Spectra Physics P1000 Solvent delivery system (Spectra Physics Analytical, Fremont, CA, 
USA). The remainder of the HPLC system consisted of a Spectra Physics model 150 UV detector set at $280 \mathrm{~nm}$, a Radiometric Instruments (Tampa, FL, USA) Flo-One/ $\beta$ radioactive flow detector and a Hewlett-Packard model 3390 A integrator. In these analytical conditions, retention times were $10.20 \mathrm{~min}$ and $16.12 \mathrm{~min}$ for $\mathrm{pNP}$ and $\mathrm{pNC}$ respectively; $\mathrm{pNP}$ and pNC were quantified using ${ }^{14} \mathrm{C}$ activity monitoring.

Glutathione $S$-transferase (GSH transferase) activity was measured by the method of Habig et al. (1974) at $20^{\circ} \mathrm{C}$ with 1-chloro-2,4-dinitrobenzene as a substrate, using a Shimadzu spectrophotometer MPS-2000.

Protein was determined by the method of Hartree (1972) with bovine serum albumin as a standard.

\section{Preparation of tissue for immunocytochemistry}

After decapitation, the olfactory rosettes were quickly removed and immersed in Bouin's solution for $24 \mathrm{~h}$. Specimens were dehydrated through graded alcohols, cleared in xylene and embedded in paraplast. Serial sections $(5-10 \mu \mathrm{m}$ thick) were cut in the coronal plane and mounted on gelatinized slides. Sections were rehydrated in distilled water. Endogenous peroxidase activity was blocked with $0.3 \% \mathrm{H}_{2} \mathrm{O}_{2}$ in distilled water or methanol for 30 $\mathrm{min}$ at room temperature. Sections were preincubated in phosphate buffer saline (PBS, $0.1 \mathrm{M}$, $\mathrm{pH} 7.4$ ) containing $0.75 \%$ gelatin and $1 \%$ normal fish serum for $1 \mathrm{~h}$ at room temperature. Sections were incubated overnight at $4{ }^{\circ} \mathrm{C}$ with a rabbit polyclonal antibody raised against perch cytochrome P4501A (Celander and Förlin 1991) diluted 1/1000 in PBS containing 1\% normal fish serum. After several washes in PBS, sections were incubated in swine anti-rabbit immunoglobulins (diluted 1:200 in PBS) for $2 \mathrm{~h}$ at room temperature. Sections were then incubated in rabbit peroxidase-antiperoxidase (PAP) complex (diluted 1:200 in PBS) for $2 \mathrm{~h}$ at room temperature. Peroxidase activity was visualized by immersion in a solution containing $0.06 \%$ $3,3^{\prime}$-diaminobenzidine tetrachloride (DAB), $0.6 \%$ nickel chloride and $0.01 \% \mathrm{H}_{2} \mathrm{O}_{2}(30 \%)$ in $0.05 \mathrm{M}$ TRIS buffer, $\mathrm{pH}$ 7.6. Sections were lightly counter- stained with cresyl violet. To demonstrate the specificity of the anti-serum to cytochrome P4501A1, some sections were incubated with normal fish serum instead of the primary antibody.

Some sections were also examined for the localization of the olfactory marker protein (OMP), a specific marker of mature olfactory receptor neurons (Margolis 1988). The goat anti-OMP antiserum was kindly provided by Dr F. Margolis. Sections were incubated in the primary antibody (diluted 1:1000 in normal fish serum) for $2 \mathrm{~h}$ at room temperature. Sections were then treated with antigoat IgG (diluted 1:100) and with a goat PAP complex (diluted 1:100) for $1 \mathrm{~h}$ at room temperature. Peroxidase was revealed by the procedure described above.

\section{Exposure of fish to $\beta$-naphthoflavone}

Twelve juvenile rainbow trout were held in a 2001 tank filled with permanently oxygenated water to which $\beta$-naphthoflavone dissolved in $1.5 \mathrm{ml}$ acetone was added for a final solution of $0.1 \mathrm{ppm}$. Six specimens were sacrificed at 2 and 4 days of exposure. Twelve fish were exposed to acetone carrier only, and were sacrificed according to the same protocol as for $\beta$-naphthoflavone-treated fish. After decapitation, the olfactory organs and the liver were removed and processed for EROD assay as described above. Each processing was performed on pooled tissues from 2 fish.

\section{Results}

\section{Enzymatic activities in control fish}

Table 1 shows that biotransformation enzymes can be detected in vitro when subcellular fractions from the olfactory organ of rainbow trout are incubated with model or endogenous substrates. Specific activities of cytochrome $\mathrm{P} 450$ reductase, pNP hydroxylase and GSH transferase were found to be at similar levels in both the olfactory organ and the liver. In contrast, microsomal EROD, ECOD, and PROD specific activities were much lower in the 
Table 1. Specific activities of xenobiotic metabolizing enzymes in the olfactory organ and the liver of rainbow trout

\begin{tabular}{|c|c|c|}
\hline & Olfactory organ & Liver \\
\hline P450-red ${ }^{1}$ & $24.8 \pm 0.25$ & $57.8 \pm 10.0$ \\
\hline EROD $^{2}$ & $0.19 \pm 0.04$ & $14.6 \pm 8.3$ \\
\hline $\mathrm{ECOD}^{2}$ & $1.7^{*}$ & $60^{*}$ \\
\hline $\mathrm{PROD}^{2}$ & $<0.13^{*}$ & $0.26^{*}$ \\
\hline p-NPH ${ }^{2}$ & $3.40 \pm 0.13$ & $6.13 \pm 0.84$ \\
\hline \multicolumn{3}{|l|}{$16 \alpha$-testosterone } \\
\hline hydroxylase $\mathrm{e}^{2}$ & $0.62 \pm 0.45$ & $<0.03$ \\
\hline \multicolumn{3}{|l|}{$16 \beta$-testosterone } \\
\hline hydroxylase $e^{2}$ & $<0.01$ & $0.16^{* *}$ \\
\hline $\mathrm{GSH}-\mathrm{t}^{3}$ & $0.78 \pm 0.04$ & $0.79 \pm 0.15$ \\
\hline
\end{tabular}

Values are mean from 3 measures \pm S.D. Each measure was done on pools of microsomes or cytosols from 6 individuals (see Materials and methods); *ECOD and PROD were measured on 1 pool; ${ }^{* *} 16 \beta$ hydroxylation of testosterone was measured on 1 pool of livers from 12 individuals. Not detectable activities are given as less than the detection limit; ${ }^{1} \mathrm{nmol} \mathrm{min}^{-1} \mathrm{mg}$ protein ${ }^{-1}$; ${ }^{2} \mathrm{pmol} \mathrm{min}^{-1} \mathrm{mg}$ protein ${ }^{-1} ;{ }^{3} \mu \mathrm{mol} \mathrm{min}^{-1} \mathrm{mg}$ protein ${ }^{-1}$.

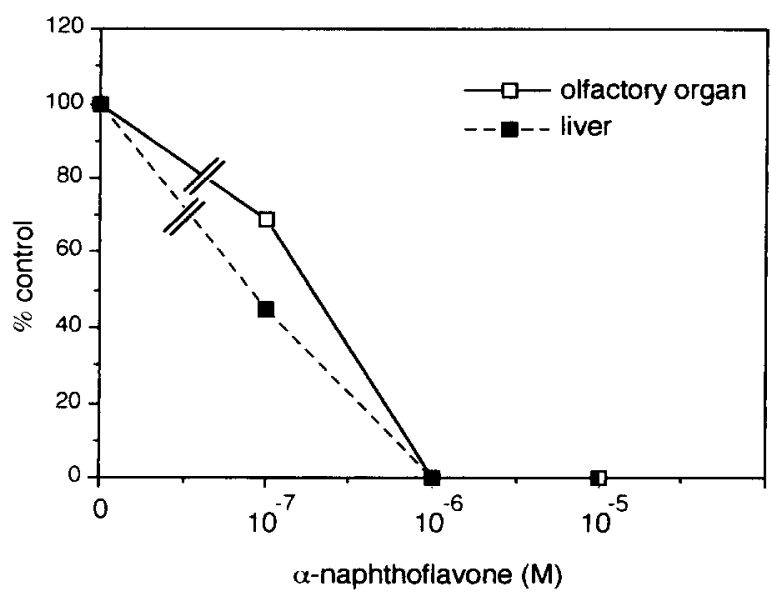

Fig. 1. Effect of $\alpha$-naphthoflavone on EROD activity in microsomes from the liver and the olfactory organ of rainbow trout. $\alpha$-Naphthoflavone in DMSO ( $1 \%$ final) was added to the incubation medium 3 min prior to addition of 7-ethoxyresorufin.

olfactory organ (77-, 35-, 200-times respectively). The hydroxylation of testosterone was qualitatively and quantitatively catalyzed quite differently in the olfactory organ compared to the liver. Microsomes from the olfactory organ were able to perform testosterone hydroxylation only in the $16 \alpha$-position while testosterone was hydroxylated in the $16 \beta$ position by liver microsomes. Furthermore, hepatic microsomes catalyzed $6 \beta$-hydroxylation of testosterone (data not shown).

The in vitro effect of $\alpha$-naphthoflavone on EROD activity measured with olfactory organ or liver microsomes is represented in Fig. 1. A 50\% inhibition of EROD activity was observed with an $\alpha$ naphthoflavone concentration which was similar in both organs (about $10^{-7} \mathrm{M}$ ).

\section{Immunocytochemical analysis in control fish}

In control rainbow trout, cytochrome P4501A1immunoreactivity appeared widely distributed in both sensory and nonsensory epithelia while no immunocytochemical staining was detected in sections reacted only with normal fish serum. In the nonsensory epithelium, particularly at the tip of the lamellae, a strong immunoreactivity was observed as well in ciliated nonsensory cells as in goblet cells and their large, flat apical process (Figs. 2 and 3). Few basal cells and small microridge cells surrounding the goblet cells exhibited a moderate staining. Some cytochrome P4501A1-immunoreactivity was also noted in the mucociliary complex at the epithelial surface (Fig. 3). In the sensory epithelium, numerous basal cells appeared well labeled and a large number of these cells was noted in the lower part of the lamellae near the raphe (Fig. 4). A weak cytochrome P4501Al-immunoreactivity which looked like a punctiform labeling was also observed throughout the sensory epithelial sheet (Figs. 2 and 4). This labeling seemed to be located in the nonsensory cellular elements, the supporting and nonsensory ciliated cells. To verify this supposition, adjacent sections were reacted with either anti-OMP antiserum (Fig. 5) or anti-cytochrome P4501Al antibody (Fig. 6). One can observe that the location of cytochrome P4501 A1-positive cells was different from that of OMP-immunoreactive cells, thus suggesting an absence of labeling in the olfactory neuroreceptors. As shown in Figs. 3 and 7, the apical pole of the nonsensory cells was particularly well immunostained and some vacuoles containing P4501A1 reaction product could be seen extruded in the rosette lumen. A few immunoreactive goblet cells could be occasionally observed. Otherwise, no 


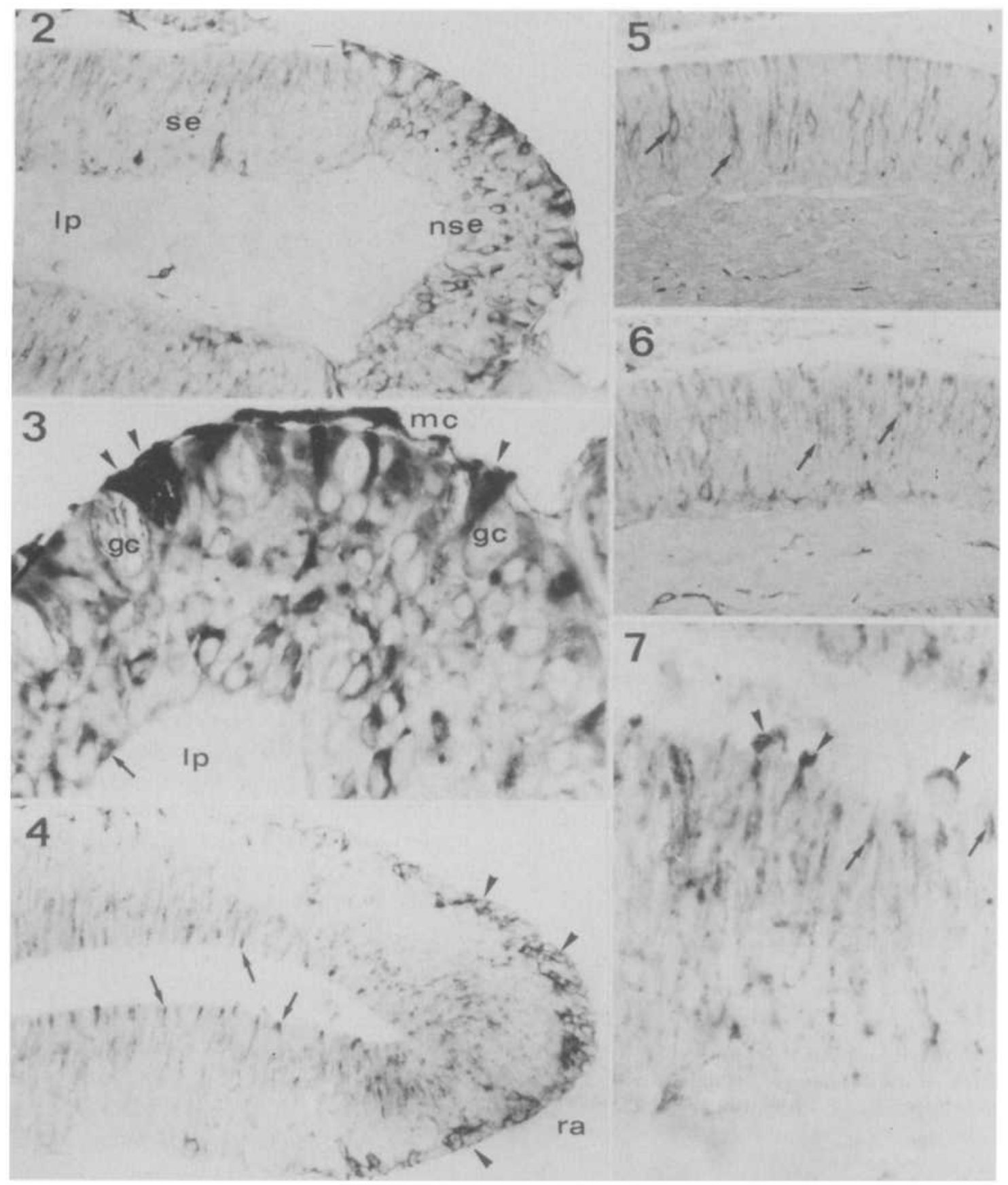

Fig. 2. Immunocytochemical localization of cytochrome P4501A1 in an olfactory lamella of a control rainbow trout. The immunostaining is widely distributed in the nonsensory (nse) and the sensory (se) epithelia while no immunoreactivity can be seen in the lamina propria (lp) $(\times 260)$.

Fig. 3. A high magnification of the nonsensory epithelium in a control fish shows that various cell types including goblet cells (gc) and their mucus secretion, ciliated nonsensory cells (arrowheads) as well as few basal cells (arrow) appear cytochrome P4501Al-immunoreactive. The mucociliary complex at the epithelial surface $(\mathrm{mc})$ is also strongly labeled. lp: lamina propria $(\times 645)$.

Fig. 4. Localization of cytochrome P4501Al-immunoreactivity in the sensory epithelium at the lower part of a lamella near its attach- 
EROD activity (pmol/min/mg protein)
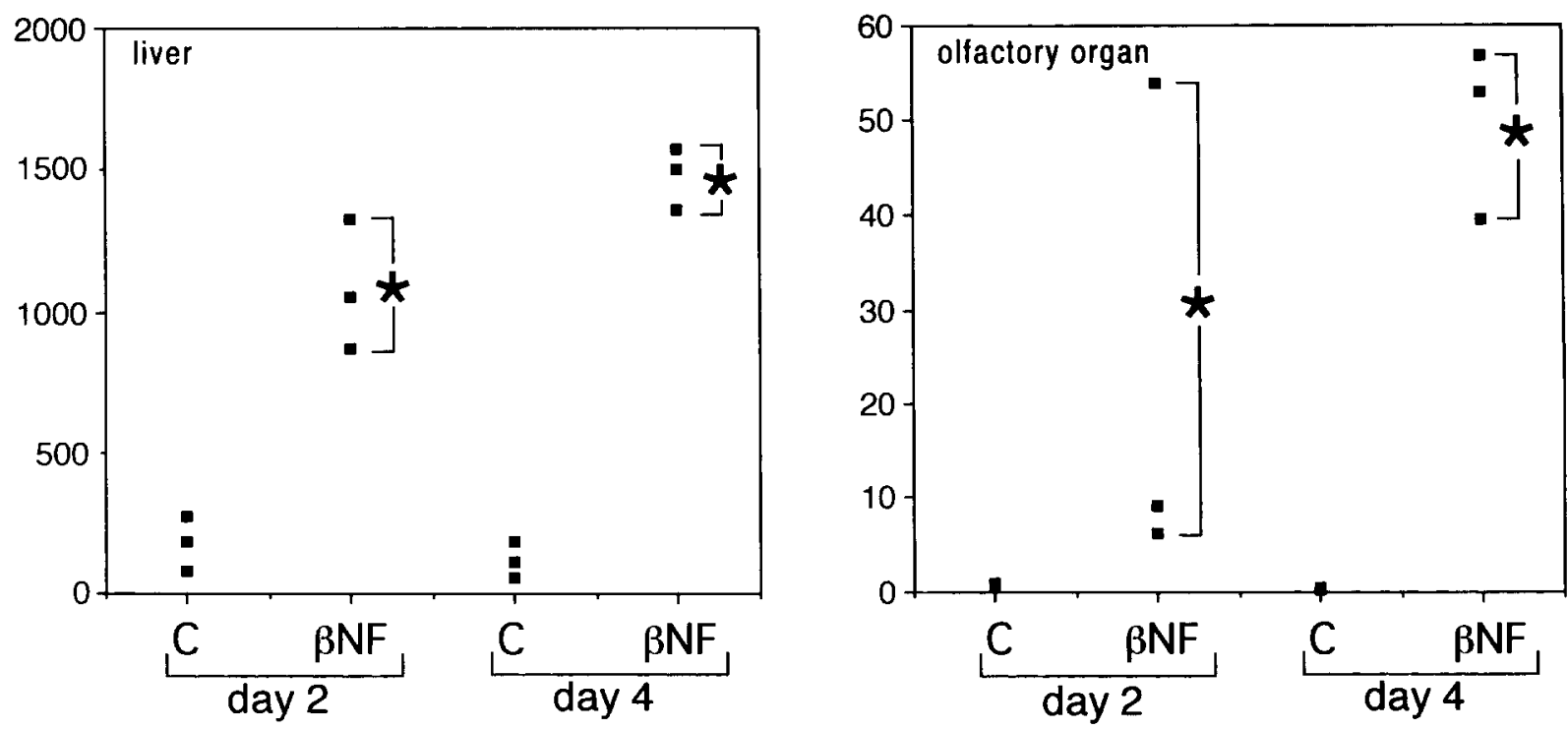

Fig. 8. Microsomal EROD activity in the liver and the olfactory organ of rainbow trout exposed to 0.1 ppm $\beta$-naphthoflavone for 2 and 4 days. $\mathrm{C}$ : control fish (acetone carrier alone); $\beta \mathrm{NF}$ : $\beta$-naphthoflavone-treated fish; each square corresponds to one analysis performed on a mixture of tissues from two fish; *significantly different from the corresponding control (Mann-Whitney $U$ test, $p<$ $0.05)$.

evident staining was detected in the lamina propria, neither in olfactory axon bundles nor in blood vessels (Fig. 2).

\section{Effect of $\beta$-naphthoflavone on EROD activity}

Figure 8 shows that the exposure of rainbow trout to $0.1 \mathrm{ppm}$ of $\beta$-naphthoflavone resulted in a marked induction of microsomal EROD activity in the liver as well as in the olfactory organ. In the two organs, EROD induction was statistically significant after 2 days of exposure and seemed to be higher after 4 days of exposure. Furthermore, the induction rate was higher in the olfactory organ than in the liver with an average EROD activity multiplied by 120 and 13 respectively, particularly after the 4-day exposure.

\section{Discussion}

Results of the present study demonstrate the presence of biotransformation enzymes in the olfactory organ of rainbow trout. According to Brittebo et al. (1986), cytochrome P450-dependent metabolism of

$-$

ment to the raphe (ra) in a control fish. A large number of basal cells (arrowheads) appears cytochrome P4501A1-positive in this area. The apical pole of several nonsensory cells (arrows) also exhibits a strong immunoreactivity near the epithelial surface $(\times 260)$.

Fig. 5. Localization of OMP-immunoreactivity in the sensory epithelium in a control fish. Arrows points to OMP-positive receptor neurons $(\times 270)$.

Fig. 6. Localization of cytochrome P4501A1-immunoreactivity in an adjacent section of that shown in Fig. 5. Localization of cytochrome P4501A1-positive cells (arrows) do not coincide with that of OMP-positive receptor neurons (arrow in Fig. 5) ( $\times 270)$.

Fig. 7. A high magnification of the sensory epithelium shows that cytochrome P4501A1-immunoreactivity looks like a punctiform labeling mainly located in the apical processes of supporting cells (arrows). Reaction products of cytochrome P4501A1 were seen extruded at the luminal surface (arrowheads) $(\times 645)$. 
phenacetin was observed when the olfactory organ of rainbow trout in culture was exposed to this chemical. Our data bring out the presence of both cytochrome P450-dependent and phase II enzymatic activities in subcellular fractions of the olfactory epithelium of rainbow trout as previously published in mammals (Dahl and Hadley 1991; Reed 1993). Nevertheless, the specific enzymatic activities are markedly lower in rainbow trout, as usually found when comparing hepatic biotransformation enzymes between fish and mammals (Chambers and Yarbrough 1976). In the present study, the comparison between hepatic and olfactory biotransformation enzyme activities assayed in subcellular fractions leads to contrasting results. Whether the in vitro conditions used to measure olfactory biotransformation enzyme activities were optimal, has not been checked due to the large amount of tissue necessary for such studies. On the contrary, the in vitro conditions used to measure hepatic activities were representative of those usually published. These latter conditions were chosen for the assays in subcellular fractions of the olfactory organ.

Among microsomal cytochrome P450-dependent monooxygenases measured, EROD, PROD, and ECOD were much lower in the olfactory organ than in the liver. In mammals, EROD and PROD activities were found at very low to undetectable levels in the olfactory epithelium, while ECOD activity often appeared higher in the olfactory epithelium than in the liver (Dahl and Hadley 1991). An explanation for the low cytochrome P450-dependent activity in the olfactory organ of rainbow trout might be found in cytochrome $\mathrm{P} 450$ reductase activity. Cytochrome $\mathrm{P} 450$ reductase catalyzes electron transfer for NADPH (or NADH) to cytochrome $\mathrm{P} 450$ and may be a rate limiting step in cytochrome P450-dependent monooxygenase activities. Nevertheless, this does not seem to be the case for EROD, ECOD and PROD in the olfactory organ of rainbow trout since these activities were much higher in the liver than in the olfactory organ, with cytochrome $\mathbf{P} 450$ reductase specific activities being quite similar in both organs. In mammals, as in our study, similar cytochrome $\mathbf{P} 450$ reductase specific activities between the liver and the olfactory epithelium have been described (Longo et al. 1991;
Reed et al. 1986). Taking altogether, the results on cytochrome $\mathbf{P} 450$ reductase and cytochrome $\mathbf{P} 450$ dependent monooxygenase activities suggest that in rainbow trout, cytochrome $\mathrm{P} 450$ forms responsible for EROD, PROD, and ECOD are poorly represented in the olfactory organ compared to the liver.

Other information on cytochrome P450-dependent metabolism in the olfactory organ was given with the measure of hydroxylation of p-nitrophenol. In mammals, this enzymatic activity has been presented as a probe for cytochrome P450 2E1, a cytochrome $\mathrm{P} 450$ form known to be involved in the metabolic activation of aromatic amines into carcinogenic derivatives and to be inducible by alcohol and acetone (Koop et al. 1989). Some studies have described cytochrome P450 2E1 in the mammalian nasal epithelium (Ding and Coon 1990). Cytochrome P450 2E1 has not been characterized in fish, nevertheless the present study demonstrates the hydroxylation of p-nitrophenol at a similar level in microsomal fractions of the olfactory organ and the liver in rainbow trout even though these activities remained 300- to 1000-times lower than those reported in mammals (Koop et al. 1989). Whether the hydroxylation of p-nitrophenol is related to the presence of cytochrome P450 2E1-like form in fish requires further studies.

Stereoselective hydroxylation of testosterone is a powerful probe to discriminate among different cytochrome P450 forms (Waxman 1988). In rabbits, the olfactory mucosa exhibits specific microsomal testosterone metabolism related to a specific cytochrome P450 form, the cytochrome P450 $\mathrm{NMb}$. It accounts for $50 \%$ of total cytochrome $\mathrm{P} 450$, but is not found in the liver (Ding and Coon 1990). Accordingly, our results suggest an olfactory-specific hydroxylation of testosterone in rainbow trout. While the hepatic microsomal metabolism was quantitatively and qualitatively in accordance with results previously published in this species (Miranda et al. 1989), 16- $\alpha$ hydroxylation has not been yet described in fish. Interestingly, $16 a$-hydroxylation has also been characterized in the nasal mucosa (especially in the olfactory mucosa) of rats (Brittebo and Rafter 1984). The involvement of such a specific enzymatic activity in the metabolism of steroid-derived pheromone has re- 
cently been proposed (Ding and Coon 1990).

Phase II enzymes in the olfactory epithelium have been described in mammals (Dahl and Hadley 1991). Our study demonstrates the occurrence of an in vitro cytosolic glutathione $S$-transferase activity in the olfactory organ of rainbow trout that was at the same level than that in the liver. This result together with that of Starcevic et al. (1993) showing an elevated concentration of glutathione in the olfactory organ of rainbow trout, suggests that the in vivo glutathione $S$-transferase activity in the olfactory organ of rainbow trout should be elevated.

In the rainbow trout liver, cytochrome P4501A1 seems to be the sole member of the 1A sub-family. This cytochrome which is usually monitored through EROD activity (Goksøyr and Förlin 1992) can be inhibited by $\alpha$-naphthoflavone (Tassaneeyakul et al. 1993). Accordingly, the similar inhibition rate of EROD activity in both the liver and the olfactory organ by $\alpha$-naphthoflavone, argues for a cytochrome P4501A1-dependent EROD activity in the rainbow trout olfactory organ.

Polyclonal antibodies raised against cytochrome P4501Al purified from perch are shown to specifically recognize cytochrome $\mathrm{P} 4501 \mathrm{~A} 1$ from the rainbow trout liver (Celander and Förlin 1991). Using these antibodies in our immunocytochemical investigation, results demonstrate that these antibodies reacted against protein(s) in the olfactory organ as well, suggesting the presence of cytochrome P4501A1 in this organ. Similarly, using monoclonal antibody raised against scup (Stenotomus crysops) cytochrome P4501A, Smolowitz et al. (1992) have demonstrated the presence of cytochrome P4501A in the olfactory organ of topminnows (Poeciliopsis sp.). In mammals, cytochrome P450 immunoreactivity has been mainly found in supporting cells and in Bowman's glands of the olfactory epithelium (Voigt et al. 1985; Adams et al. 1991; Baron 1991; Ding and Coon 1991; Zupko et al. 1991; Chen et al. 1992; Walker et al. 1992; Voigt et al. 1993). As a whole, results of the present study are in accordance with mammalian literature. In rainbow trout, cytochrome P4501A1-immunoreactivity was strongly detected in various cellular types forming the nonsensory epithelium including goblet cells, microridge cells and ciliated nonsenso- ry cells. Immunostaining was also reported in the nonsensory cellular elements constituting the sensory epithelium. The absence of cytochrome P4501A1 in the olfactory receptor cells has been suggested in mammals (Adams et al. 1991; Chen et al. 1992). The rainbow trout olfactory neurons identified by anti-OMP antiserum, did not react with antiP4501A1 antibody. The cellular distribution of other cytochromes $\mathrm{P} 450$ in the olfactory organ should be interesting to investigate in rainbow trout, since Voigt et al. (1993) have shown different distributions of cytochrome P4501A1 and 2B1 in the rat olfactory epithelium.

$\beta$-naphthoflavone is a model inducer of hepatic cytochrome P4501A1 in rainbow trout (Goksøyr and Förlin 1992). In our study, the exposure of rainbow trout to waterborne $\beta$-naphthoflavone at a concentration of $0.1 \mathrm{mg} \mathrm{l}^{-1}$ resulted in an induction of EROD activity which was stronger in the olfactory organ than in the liver. Whether this difference is dependent on the toxicokinetic of $\beta$ naphthoflavone or a tissue-specific response is a matter of further studies. In the present study, the induction ratc of EROD activity in the liver of rainbow trout was in the same range as that observed by Haasch et al. (1993) who used similar conditions of exposure. The immunocytochemical analysis in the olfactory organ of $\beta$-naphthoflavone-treated rainbow trout shows a cytochrome P4501A1-immunoreactivity in all cell types described as positive in control fish plus in blood vessels in the lamina propria (Saucier et al., unpublished data). Recently, using monoclonal antibody raised against scup cytochrome P4501A, Smolowitz et al. (1992) have suggested that cytochrome P4501A induction may take place in the olfactory epithelium of topminnow exposed for 2 days to benzo(a)pyrene at a concentration of $1 \mathrm{mg}$ I I. In mammals, cytochrome $\mathrm{P} 4501 \mathrm{Al}$ has been described as poorly inducible in the olfactory epithelium (Dahl and Hadley 1991; Reed 1993), although Voigt et al. (1993), using an immunocytochemical technique, have demonstrated such an induction in the olfactory epithelium of rats pretreated with Aroclor 1254 .

Recent papers have suggested that biotransformation enzymes in the olfactory organ may be involved in detoxication of organic micropollutants 
(Dahl and Hadley 1991; Reed 1993). This function should be important in fish since their olfactory organ is in direct and permanent contact with waterborne pollutants. Moreover, the olfactory neuroreceptors provide a direct access to the central nervous system with their axons ending in the olfactory bulb. Although most of the cytochrome P450dependent enzymatic activities were detected only at a low level in the rainbow trout olfactory organ (on a whole tissue basis), the immunocytochemical analysis showed an intense cytochrome P4501A1immunoreactivity in specific cellular types. Therefore, the low specific EROD activity measured in microsomes from the whole olfactory organ could be at least partly due to the dilution of microsomes from the cytochrome P4501A1-containing cells by microsomes from cytochrome P4501A1-free cells. Interestingly, cytochrome P4501A1-immunoreactivity was largely detected in mucus secreting cells. The observation of vesicles filled with reaction product at the epithelial surface of the sensory epithelium, should argue for an extracellular action of this enzyme. This is reinforced by the observation of the large amount of reaction product in the mucociliary complex and in the secretion product of goblet cells. Thus, the strong inducibility of EROD activity observed in the present study, might be an efficient adaptative response to facilitate clearance of waterborne pollutants that may exert neurotoxic effects.

Cytochrome P4501 A1 is involved in the transformation of polycyclic aromatic hydrocarbons into reactive metabolites (Guenguerich 1992). Accordingly, the high concentration of cytochrome P4501A1 in various cellular types as well as its inducibility, question the toxicological consequences that may arise from their exposure to these widespread pollutants. Using the same antibodies as in the present study, this question has been recently pointed out by Andersson et al. (1993) showing the presence of cytochrome P4501A1 in specific cells of the rainbow trout pituitary. Nevertheless, our study showing elevated specific glutathione $S$-transferase activity, together with that of Starcevic et al. (1993) showing a high glutathione concentration, argues for a high detoxication activity capable of neutralizing the reactive metabolites originating from cytochrome P4501A1 activity in the olfactory organ of rainbow trout.

Recently, Nebert (1991) has generalized the role of biotransformation enzymes, considering their involvement in signal transduction pathways which effect major functions in living organisms. These enzymes should play a key role in regulating the levels of ligands that effect growth, homeostasis, differentiation, neuroendocrine, as well as sensory functions, primary to their involvement in pollutant metabolism. According to this proposal, cytochrome P450 and UDP-glucuronosyl transferase forms, specific to the olfactory epithelium, have been characterized in rats (Nef et al. 1989; Lazard et al. 1991) and rabbits (Ding and Coon 1988). Moreover, a recent study has demonstrated that glutathione $S$-transferase of the rat olfactory epithelium was involved in the conjugation of natural odorants (Ben-Arie et al. 1993). Taken all together, these results argue for the involvement of biotransformation enzymes in regulation of the odorant signal (starting/termination) in the olfactory epithelium. Results of the present study confirm that these questions should be investigated in fish.

In conclusion, this study demonstrates the presence of biotransformation enzymes in subcellular fractions of the olfactory organ in rainbow trout. Using polyclonal antibodies, cytochrome P4501 A1 was shown to be well represented in several cellular types except olfactory receptor cells. Results of waterborne exposure to $\beta$-naphthoflavone led to the conclusion that olfactory cytochrome P4501A1 was highly inducible. The presence of such enzyme activities in the olfactory organ of rainbow trout addresses the question of their involvement in the detoxication/toxication of pollutants as well as in olfactory function.

\section{Acknowledgements}

This research was supported by the CNRS (URA 180), the INRA, and the Centre Jacques Cartier. Polyclonal antibodies raised against perch cytochrome P4501Al were kindly provided by Dr. L. Förlin. 


\section{References cited}

Adams, D.R., Jones, A.M., Plopper, C.G., Serabijt-Singh, C.J. and Philpot, R.M. 1991. Distribution of cytochrome P-450 monoxygenase enzymes in the nasal mucosa of hamster and rat. Am. J. Anat. 190: 291-298.

Andersson, T., Förlin, L., Olsen, S., Fostier, A. and Breton, B. 1993. Pituitary as a target organ for toxic effects of P4501A1 inducing chemicals. Mol. Cell. Endocrinol. 91: 99-105.

Baron, J. 1991. In situ sites for xenobiotic activation and detoxication: implications for the differential susceptibility of cells to the toxic actions of environmental chemicals. In Progress in Histo- and Cytochemistry. Vol. 23, Histo- and Cytochemistry as a Tool in Environmental Toxicology. pp. 32-44. Edited by W. Graumann and J. Drukker. Fisher Verlag, Stuttgart-New York.

Ben-Arie, N., Khen, M. and Lancet, D. 1993. Glutathione Stransferases in rat olfactory epithelium: purification, molecular properties and odorant biotransformation. Biochem. J. 292: 379-384.

Brittebo, E.B., Darnerud, P.O., Larsson, J., Svanberg, O. and Brandt, I. 1986. O-dealkylation of phenacetin in the olfactory rosette in rainbow trout (Salmo gairdneri). Acta Pharmacol. Toxicol. 58: 259-264.

Brittebo, E.B. and Rafter, J.J. 1984. Steroid metabolism by rat nasal mucosa: studies on progesterone and testosterone. $\mathbf{J}$. Steroid Biochem. 20: 1147-1151.

Celander, M. and Förlin, L. 1991. Catalytic activity and immunochemical quantification of hepatic cytochrome P-450 in $\beta$-naphthoflavone and isosafrol treated rainbow trout $(\mathrm{On}$ corhynchus mykiss). Fish Physiol. Biochem. 9: 189-197.

Chambers, J.E. and Yarbrough, J.D. 1976. Xenobiotic biotransformation systems in fishes. Comp. Biochem. Physiol. 55C: $77-84$.

Chen, Y., Getchell, M.L., Ding, X. and Getchell, T.V. 1992. Immunolocalization of two cytochrome $\mathrm{P} 450$ isozymes in rat nasal chemosensory tissue. NeuroReport 3: 749-752.

Dahl, A.R. and Hadley, W.M. 1991. Nasal cavity enzymes involved in xenobiotic metabolism: effects on the toxicity of inhalants. CRC Crit. Rev. Toxicol. 21: 345-372.

Ding, X. and Coon, M.J. 1988. Purification and characterization of two unique forms of cytochrome P-450 from rabbit nasal microsomes. Biochem. J. 27: 8330-8337.

Ding, X. and Coon, M.J. 1990. Immunochemical characterization of multiple forms of cytochrome P-450 in rabbit nasal microsomes and evidence for tissue-specific expression of P-450s NMa and NMb. Mol. Biol. 37: 489-496.

Ding, X. and Coon, M.J. 1991. Interaction of odorants and endogenous substrates with olfactory mono-oxygenases: possible role of cytochrome P-450 in the maintenance of steroid and fatty acid homeostasis in rabbit olfactory mucosa. Chem. Senses 16: 513-514.

Goksøyr, A. and Förlin, L. 1992. The cytochrome P-450 system in fish, aquatic toxicology and environmental monitoring. Aquat. Toxicol. 22: 287-312.
Guenguerich, F.P. 1992. Metabolic activation of carcinogens. Pharmacol. Ther. 54: 17-61.

Haasch, M.L., Quardokus, E.M., Sutherland, L.A., Goodrich, M.S. and Lech, J.J. 1993. Hepatic CYP1A1 induction in rainbow trout by continuous flowthrough exposure to $\beta$-naphthoflavone. Fund. Appl. Toxicol. 20: 72-82.

Habig, W.H., Pabst, M.J. and Jakoby, W.B. 1974. Glutathione S-transferase: the first enzymatic step in mercapturic acid formation. J. Biol. Chem. 249: 7130-7139.

Hara, T.J. 1993. Role of olfaction in fish behavior. In Behavior of Teleost Fishes. pp. 171-199. Edited by T.J. Pitcher. Chapman and Hall, London.

Hartree, E.F. 1972. Determination of protein, a modification of the Lowry method that gives a linear photometric response. Analyt. Biochem. 48: 422-427.

Klaprat, D.A., Evans, R.A. and Hara, T.J. 1992. Environmental contaminants and chemoreception in fishes. In Fish Chemoreception. pp. 321-341. Edited by T.J. Hara. Chapman and Hall, London.

Koop, D.R., Laethem, C.L. and Tierney, D.J. 1989. The utility of $p$-nitrophenol hydroxylation in P450IIE1 analysis. Drug Metab. Rev. 20: 541-551.

Lazard, D., Zupko, K., Poria, Y., Nef, P., Lazarovits, J., Horn, S., Khen, M. and Lancet, D. 1991. Odorant signal termination by olfactory UDP glucuronosyl transferase. Nature, Lond. 349: 790-793.

Longo, V., Mazzaccaro, A., Naldi, F. and Gervasi, P.G. 1991. Drug-metabolizing enzymes in liver, olfactory, and respiratory epithelium of cattle. J. Biochem. Toxicol. 6: 123-128.

Margolis, F.L. 1988. Molecular cloning of olfactory specific gene products. In Molecular Neurobiology of the Olfactory System. pp. 237-265. Edited by F.L. Margolis and T.V.G. Getchell. Plenum Press, New York.

Miranda, C.L., Wang, J.-L., Henderson, M.C. and Buhler, D.R. 1989. Purification and characterization of hepatic steroid hydroxylases from untreated rainbow trout. Arch. Biochem. Biophys. 268: 227-238.

Monod, G., Devaux, A. and Rivière, J.-L. 1987. Characterization of some monooxygenase activities and solubilization of hepatic cytochrome P-450 in two species of freshwater fish, the nase (Chondrostoma nasus) and the roach (Rutilus rutilus). Comp. Biochem. Physiol. 88C: 83-89.

Monod, G., Devaux, A. and Rivière, J.-L. 1988. Effects of chemical pollution on the activities of hepatic xenobiotic metabolizing enzymes in fish from the River Rhône. Sci. Total Environ. 73: 189-201.

Nebert, D.W. 1991. Proposed role of drug-metabolizing enzymes: regulation of steady state levels of the ligands that effect growth, homeostasis, differentiation, and neuroendocrine functions. Mol. Endocrinol. 5: 1203-1214.

Nebert, D.W., Puga, A. and Vasiliou, V. 1993. Role of the Ah receptor and the dioxin-inducible [Ah] gene battery in toxicity, cancer, and signal transduction. Ann. New York Acad. Sci. 685: 624-640.

Nef, P., Heldman, J., Lazard, D., Margalit, T., Jaye, M., Hanukoglu, I. and Lancet, D. 1989. Olfactory-specific cyto- 
chrome P-450. cDNA cloning of a novel neuroepithelial enzyme possibly involved in chemoreception. J. Biol. Chem. 264: 6780-6785.

Okey, A.B. 1990. Enzyme induction in the cytochrome P-450 system. Pharmacol. Ther. 45: 241-298.

Payne, J.F., Fancey, L.L., Rahimtula, A.D. and Porter, E.L. 1987. Review and perspective on the use of mixed-function oxygenase enzymes in biological monitoring. Comp. Biochem. Physiol. 86C: 233-245.

Perdu-Durand, E. and Tulliez, J.E. 1985. Hydrocarbon hydroxylation system in liver microsomes from four animal species. Fd. Chem. Toxic. 23: 363-366.

Reed, C.J., Lock, E.A. and De Matteis, F. 1986. NADPH:cytochrome $\mathrm{P}-450$ reductase in olfactory epithelium. Relevance to cytochrome P-450-dependent reactions. Biochem. J. 240: 585-592.

Reed, C.J. 1993. Drug metabolism in the nasal cavity: relevance to toxicology. Drug Metab. Rev. 25: 173-205.

Saucier, D., Astic, L. and Rioux, P. 1991. The effects of early chronic exposure to sublethal copper on the olfactory discrimination of rainbow trout, Oncorhynchus mykiss. Environ. Biol. Fish. 30: 345-351.

Smolowitz, R.M., Schultz, M.E. and Stegeman, J.J. 1992. Cytochrome P4501 A induction in tissues, including olfactory epithelium, of topminnows (Poeciliopsis spp.) by waterborne benzo[a]pyrene. Carcinogenesis 13: 2395-2402.

Starcevic, S.L., Muruganandam, A., Mutus, B. and Zielinski, B.S. 1993. Glutathione in the olfactory mucosa of rainbow trout (Oncorhynchus mykiss). Chem. Senses 18: 57-65.

Tassaneeyakul, W., Birkett, D.J., Veronese, M.E., McManus, M.E., Tukey, R.H., Quattrochi, L.C., Gelboin, H.V. and
Miniers, J.O. 1993. Specificity of substrate and inhibitor probes for human cytochromes P450 1A1 and 1A2. J. Pharmacol. Exp. Ther. 265: 401-407.

Voigt, J.M., Guengerich, E.P. and Baron, J. 1985. Localization of a cytochrome $P-450$ isozyme (cytochrome P-450 PB-B) and NADPH-cytochrome $P-450$ reductase in rat nasal mucosa. Cancer Lett. 27: 241-247.

Voigt, J.M., Guengerich, F.P. and Baron, J. 1993. Localization and induction of cytochrome P450 $1 \mathrm{~A} 1$ and aryl hydrocarbon hydroxylase activity in rat nasal mucosa. J. Histochem. Cytochem. 41: 877-885.

Walker, E., Buchheit, K. and Maruniak, J.A. 1992. Receptor neuron loses result in decreased cytochrome P-450 immunoreactivity in associated non-neuronal cells of mouse olfactory mucosa. J. Neurosci. Res. 33: 103-111.

Waxman, D.J., Ko, A. and Walsh, C. 1983. Regioselectivity and stereoselectivity of androgen hydroxylations catalyzed by cytochrome P-450 isozymes purified from phenobarbital-induced rat liver. J. Biol. Chem. 258: 11937-11947.

Waxman, D.J. 1988. Interactions of hepatic cytochromes P-450 with steroid hormones. Regioselectivity and stereospecificity of steroid metabolism and hormonal regulation of rat P-450 enzyme expression. Biochem. Pharmacol. 37: 71-84.

Wood, A.W., Ryan, D.E., Thomas, P.E. and Levin, W. 1983. Regio- and stereoselective metabolism of two $\mathrm{C}_{19}$ steroids by five highly purified and reconstituted rat hepatocyte cytochrome P-450 isozymes. J. Biol. Chem. 258: 8839-8847.

Zupko, K., Poria, Y. and Lancet, D. 1991. Immunolocalization of cytochromes $P-450 \mathrm{olf} 1$ and $P$-450olf2 in rat olfactory mucosa. Eur. J. Biochem. 196: 51-58. 